\title{
Fall and Winter Habitat Use by Scaled Quail in Southeastern Arizona
}

\author{
Kirby D. Bristow ${ }^{1}$ and Richard A. Ockenfels ${ }^{2}$ \\ Authors are ${ }^{1}$ Associate Research Biologist and ${ }^{2}$ Research Program Supervisor, \\ Arizona Game and Fish Department, 2221 W Greenway Rd, Phoenix, AZ 85023.
}

\begin{abstract}
Scaled quail (Callipepla squamata pallida Vigors) are closely associated with semidesert grasslands of the southwestern United States, and populations have declined by as much as $50 \%$ since 1960 . Livestock grazing, shrub encroachment, and exotic grass invasion are considered important factors reducing scaled quail distribution and density in Arizona. We investigated habitat use by scaled quail across their range in southeastern Arizona to determine the habitat conditions important for survival and reproduction. Pointing dogs located quail during autumn and winter of 2002-2003 and 2003-2004, and we measured habitat characteristics at 52 flush sites and 54 nonuse plots, where scaled quail were not found. We recorded information on landform, substrate, vegetation, and cover. Scaled quail used areas with grass canopy cover $\geq 26 \%$, tree canopy cover $\leq 10 \%$, and higher grass species richness than randomly available. Short ( $\leq 50 \mathrm{~cm}$ tall) visual obstruction (i.e., cover), usually associated with low shrubs, cacti, and bunchgrass, was greater at use sites than at nonuse plots. A logistic-regression equation, including visual obstruction and tree canopy variables, correctly predicted $\geq 91 \%$ of quail use sites. Greater amounts of visual obstruction and lower percentages of tree canopy cover best-predicted scaled quail sites. Land management practices that reduce grass species richness and cover and increase tree cover may reduce scaled quail habitat quality and availability in southeastern Arizona. Based on habitat use patterns of scaled quail, we recommend that semidesert grassland habitats contain a maximum tree canopy of $<6 \%$ and $>25 \%$ grass canopy cover at the $20-\mathrm{cm}$ height to provide optimum cover availability.
\end{abstract}

\section{Resumen}

Las "Scaled quail" (Callipepla squamata pallida Vigors) están íntimamente asociadas con los pastizales semidesérticos del Sudoeste de los Estados Unidos de América, y desde 1960 sus poblaciones han disminuido hasta en un $50 \%$. El apacentamiento de ganado, la expansión de especies leñosas y la invasión de especies exóticas de zacates son considerados como factores importantes en la reducción de la distribución y densidad del "scaled quail" en Arizona. Investigamos el uso del hábitat por el "scaled quail" a lo largo de su rango de distribución en el sudeste de Arizona para determinar las condiciones de hábitat importantes para su supervivencia y reproducción. Mediante el uso de perros de presa se localizaron las "scaled quail" durante el otoño e invierno de 2002-2003 y 2003-2004, y medimos las características del hábitat en 52 sitios con cobertura no segura para estas aves y 54 sitios sin uso en los que no se encontraron ejemplares de "scaled quail." Registramos información sobre la forma topográfica, substrato, vegetación y cobertura. La "scaled quail" uso áreas con una cobertura aérea de zacates $\geq 26 \%$, una cobertura de copa de árboles $\leq 10 \%$ y una mayor riqueza de especies de zacates que los disponibles aleatoriamente. Una obstrucción visual corta (cobertura), $\leq 50 \mathrm{~cm}$ de alto, usualmente asociada con arbustos bajos, cactáceas y zacates amacollados, fue mayor en los sitios con uso que en los sin uso. Una ecuación de regresión logística que incluye las variables de obstrucción visual y la copa de los árboles perdijó correctamente $\geq 91 \%$ de los sitios de uso del "scaled quail." Mayores cantidades de obstrucción visual y un porcentaje más bajo de cobertura de copa de árboles predijeron mejor los sitios de "scaled quail." Las prácticas de manejo que reducen la riqueza y cobertura de especies de zacates e incrementan la cobertura de árboles pueden reducir la calidad del hábitat del "scaled quail" y su disponibilidad en el sudeste de Arizona. Basados en los patrones de uso del "scaled quail," recomendamos que los hábitats de pastizal semidesértico contengan una cobertura de copa de árboles máxima de $<6 \%$ y una cobertura aérea de zacates de $>25 \%$ a una altura de $20 \mathrm{~cm}$ para suministrar una disponibilidad de cobertura óptima.

Key Words: Callipepla squamata, grazing, livestock, exotic grasses, semidesert grasslands, Chihuahuan desertscrub

\section{INTRODUCTION}

Scaled quail (Callipepla squamata pallida Vigors) inhabit the Chihuahuan Desert and associated desert grasslands of the southwestern United States and northern Mexico (Schemnitz 1994). In Arizona, scaled quail are mainly restricted to south-

Funding for this study was provided by the Federal Aid in Wildlife Restoration Act through Project W-78-R of the Arizona Game and Fish Department.

Correspondence: Mr Kirby D. Bristow, Arizona Game and Fish Department, $2221 \mathrm{~W}$ Greenway Rd, Phoenix, AZ 85023. Email: kbristow@azgfd.gov

Manuscript received 24 August 2004; manuscript accepted 2 March 2006. eastern valleys with climates characterized by a summer rainfall regime; areas that have $\leq 40 \%$ of the annual precipitation falling between April and August do not support scaled quail (Brown 1989). Scaled quail inhabit relatively flat, open grassland and desert areas with sparse vegetation and less ground cover than that preferred by Montezuma quail (Cyrtonyx Montezumae mearnsi Vigors; Brown 1978). Although these areas can have a substantial shrub component, scaled quail avoid dense thickets of tall $(>1 \mathrm{~m})$ shrubs and tree-lined washes (Medina 1988). Unlike Gambel's quail (Callipepla gambelii Gambel), scaled quail roost on the ground (Stormer 1984). 
Scaled quail populations have declined by as much as $50 \%$ across their range in the United States since 1960 (Brennan 1994; Saiwana et al. 1998). Although locally they can be abundant and are the most common game bird in New Mexico, scaled quail in Arizona are not as abundant or widely distributed as Gambel's quail (Brown 1989). Scaled quail populations on the edge of their range in Arizona have declined since 1979 (Arizona Game and Fish Department, unpublished data, 2003). Causes for these declines are not documented, but scrub invasion is often implicated (Brown 1989). Desert grassland areas that have been exposed to decades of heavy livestock grazing are often transformed into desertscrub (Brown 1978). In these areas, scaled quail often overlap with Gambel's quail. As trees and desertscrub replace perennial grasslands, Gambel's quail replace scaled quail (Brown 1989).

Although the habitat use of scaled quail is fairly well understood in other states, the level of knowledge in Arizona is less well developed (Brown 1989). General habitat preferences of a given species are likely consistent throughout their range; however, site-specific habitat use can be greatly affected by quality of available habitat (Arthur et al. 1996). Our objective was to identify vegetative characteristics that affect scaled quail habitat use and provide habitat models to improve land management recommendations. Information on habitat use patterns of scaled quail in Arizona is needed to adequately determine likely causes of decline and to help design land management plans to protect, enhance, and restore fall and winter habitats, enhancing annual survival.

\section{MATERIALS AND METHODS}

\section{Study Area}

We conducted this study across $67 \%$ of scaled quail range in southeastern Arizona. The vegetation associations consisted primarily of semidesert grasslands (Brown 1994a) and Chihuahuan (Brown 1994b) and Sonoran desertscrub (Turner and Brown 1994). These areas were dominated by perennial bunchgrasses, such as tobosa grass (Pleuraphis mutica Benth.), grama grasses (Bouteloua Lag. spp.), lovegrasses (Eragrostis Beauv. spp.), and cottontop (Trichachne Nees. spp.), interspersed with low shrubs, such as snakeweed (Gutierrezia sarothrae Pursh.) and bursages (Franseria Cav. spp.; Brown 1994a). Catclaw (Mimosa biuncifera Benth.), acacia (Acacia Mill. spp.), soap tree yucca (Yucca elata Engelm.), and shrubform mesquites (Prosopis L. spp.), were common midlevel shrubs (Brown 1994b). Trees, such as mesquite, foothill palo verde (Cercidium microphyllum Torr.), desert hackberry (Celtis pallida Torr.), and juniper (Juniperus L. spp.), were present and dominated some sites (Turner and Brown 1994). Cacti, such as prickly pear and chollas (Opuntia Mill. spp.) were common in most areas (Turner and Brown 1994).

Topography consisted of extensive valleys and flats continuing upward to rolling hills broken by small canyons, and mesas; elevation ranged between 750-1 $600 \mathrm{~m}$. Average annual precipitation was $365 \mathrm{~mm}$ at Douglas, Arizona, and $303 \mathrm{~mm}$ at Tucson, Arizona, on the east and western ends of the study area, respectively. Annual precipitation was bimodal with peaks in winter and late summer. The percentage of rain falling during the summer months was higher $(\geq 50 \%)$ in the eastern portions of the study area. Seasonal maximum temperatures at Willcox, Arizona (central portion of the study area), averaged $34.0^{\circ} \mathrm{C}$ and $15.7^{\circ} \mathrm{C}$ for summer and winter, respectively (National Oceanic and Atmospheric Administration 2003).

We restricted our investigations to public land, which comprised approximately $75 \%$ of the study area. Arizona State Land Department managed most $(78 \%)$ of the public land within the study area, the remainder falling under the jurisdiction of the US Bureau of Land Management (19\%) and the US Forest Service $(3 \%)$. Recreation and cattle grazing were common land uses within this area. Range conditions within the study area varied from overused to lightly used, some pastures being temporarily deferred from grazing.

\section{Habitat Measurements}

To establish the presence or absence of scaled quail, we conducted surveys $(N=101)$ with pointing dogs within randomly generated $2.6-\mathrm{km}^{2}$ blocks inside the previously described range of scaled quail in southeastern Arizona (Brown 1989). Each survey consisted of a 2 -hour search throughout the entire $2.6-\mathrm{km}^{2}$ random block, using 1-3 experienced dogs and 1-2 observers. We conducted surveys between 1 October and 28 March in 2002 to 2004 . We recorded date and time of day and used a Global Positioning System unit to obtain Universal Transverse Mercator coordinates for each site. We estimated total covey size and covey activity and centered habitat component measurements at the approximate center of each site where we first observed scaled quail (flush site).

We described landform of flush sites by measuring slope, aspect, and classifying terrain type, based upon position on a slope. We measured degree of slope with a clinometer and aspect of slope $\left(0-359^{\circ}\right)$ with a compass. We assigned each site a terrain category of ridgetop, upper half of ridge, lower half of ridge, mesa, valley floor, or drainage bottom.

\section{Vegetation Sampling}

At flush sites, we estimated vegetative species composition and structure within a $100-\mathrm{m}^{2}$ circular plot (radius $=5.6 \mathrm{~m}$ ). We estimated species richness by counting the number of grass, forb, shrub, cactus, and tree species. We identified the species of the nearest tree, then measured distance $(\mathrm{m})$ to, and diameter $(\mathrm{DBH}=$ diameter in $\mathrm{cm}$ at $1.2 \mathrm{~m}$ high) of, that tree. We also recorded distance $(\mathrm{m})$ to, and species of, the nearest shrub.

We estimated the percentage of ground and canopy cover within a 25 -m radius circle using 4 perpendicular transects that intersected on flush site centers. This method yielded 100 points oriented in 4 directions at $1-\mathrm{m}$ intervals. The first transect line was randomly oriented, and subsequent lines were oriented by increasing $90^{\circ}$ from the previous line. At each $1-\mathrm{m}$ point, we recorded ground cover (vegetation or substrate material on the ground at the $1-\mathrm{m}$ point) and all vegetation that could provide canopy cover for a quail ( $>10-\mathrm{cm}$ high). We classified ground cover as grass, forb, shrub, cactus, tree, rocks, litter, or bare ground. We classified canopy cover as grass, forb, shrub, cactus, or tree. We estimated the percentage of ground and canopy cover as the total number of hits within each class. We estimated the average grass height at each site by recording the grass height at each of the first $10,1-\mathrm{m}$ points in which we encountered grass along transects and by calculating the mean. 
Table 1. Habitat variables at scaled quail flush sites $(n=52)$ that did not differ $(P>0.0083)$ from nonuse plots $(n=54)$ in southeastern Arizona, October-March, 2002-2004.

\begin{tabular}{lccc}
\hline & \multicolumn{2}{c}{ Mean \pm SD } & \\
\cline { 2 - 3 } Variable & Flush & Nonuse & $P^{1}$ \\
\hline Slope (degrees) & $4.3 \pm 4.8$ & $3.8 \pm 4.9$ & 0.588 \\
Forb species richness & $2.9 \pm 1.4$ & $2.8 \pm 1.4$ & 0.591 \\
Shrub species richness & $2.2 \pm 1.1$ & $2.4 \pm 1.2$ & 0.527 \\
Cactus species richness & $1.2 \pm 1.2$ & $1.2 \pm 1.4$ & 0.788 \\
DBH of nearest tree (cm) & $4.4 \pm 3.0$ & $7.4 \pm 7.6$ & 0.009 \\
Distance to nearest shrub (m) & $1.8 \pm 2.1$ & $2.3 \pm 2.3$ & 0.252 \\
Forb ground cover (\%) & $9.9 \pm 9.9$ & $13.4 \pm 13.5$ & 0.136 \\
Shrub ground cover (\%) & $4.0 \pm 5.1$ & $3.4 \pm 4.0$ & 0.506 \\
Cacti ground cover (\%) & $1.6 \pm 2.7$ & $0.9 \pm 1.8$ & 0.121 \\
Tree ground cover (\%) & $0.1 \pm 0.2$ & $0.3 \pm 0.8$ & 0.022 \\
Litter ground cover (\%) & $15.1 \pm 10.9$ & $19.6 \pm 12.6$ & 0.049 \\
Forb canopy cover (\%) & $7.5 \pm 9.0$ & $4.4 \pm 6.5$ & 0.047 \\
Shrub canopy cover (\%) & $13.9 \pm 9.2$ & $12.3 \pm 12.3$ & 0.451 \\
Cacti canopy cover (\%) & $4.4 \pm 7.7$ & $2.2 \pm 4.1$ & 0.077 \\
\hline
\end{tabular}

${ }^{1}$ Differences determined by 2-sample $t$ tests.

We used 2 methods to measure vertical structure around flush sites; both methods estimated visual obstruction (from vegetation, topography, etc.) when viewed from a 1-m height. The first method was a 1-m Robel pole (Robel et al. 1970) marked off in $10-\mathrm{cm}$ increments centered on the flush site. We centered the Robel pole vertically on the flush site and estimated the percentage of the $10-\mathrm{cm}$ and $20-\mathrm{cm}$ bands visible from $10 \mathrm{~m}$ along each of our 4 transect lines, then averaged the 4 readings. Because low-level vertical structure in southeastern Arizona often occurs in a patchy distribution, we also measured visual obstruction over a larger area using a $2500-\mathrm{cm}^{2}$ visibility board with a $5-\mathrm{cm}$ grid. The board had 10 height classes, each with 10 intersections, as in Bristow and Ockenfels (2004). We centered the board vertically on the flush site and counted the number of intersections visible at each height from a distance of $4 \mathrm{~m}$, as in Bristow and Ockenfels (2004). We took 4 measurements oriented along transect lines, then averaged values for each height class.

\section{Nonuse Plots}

We measured habitat variables in the same manner and during the same seasons at flush sites and nonuse plots. We located nonuse plots by traveling a random number of paces (0-100), in a random direction $\left(0-360^{\circ}\right)$, from access points within 2.6$\mathrm{km}^{2}$ areas where scaled quail were not found during previous surveys. We used a random-numbers table to determine direction and number of paces (Zar 1984).

\section{Statistical Analysis}

We compared habitat measurements from quail flush sites with habitat measurements collected at nonuse plots to determine which factors influenced habitat use. We used 2-sample $t$ tests for all continuous data sets (Zar 1984). We performed multiple tests of variables with a potential lack of independence and, therefore, applied Bonferroni corrections to adjust $\alpha$ levels from 0.1 to 0.0083 (Hochberg 1988). For categorical data, we
Table 2. Use of slope aspect $(n=85)$ and terrain classes $(n=106)$ at scaled quail flush sites $(n=52)$ compared with nonuse plots in southeastern Arizona, October-March, 2002-2004.

\begin{tabular}{|c|c|c|c|c|}
\hline Aspect/terrain class & $\begin{array}{c}\text { No. of } \\
\text { locations }\end{array}$ & $\begin{array}{c}\text { No. of } \\
\text { locations } \\
\text { expected }\end{array}$ & $\begin{array}{c}\text { Bonferroni } \\
90 \% \mathrm{Cl}\end{array}$ & $\begin{array}{c}\text { Jacobs' } \\
D^{1}\end{array}$ \\
\hline $316-360^{\circ}$ and $0-45^{\circ}$ & 9 & 8 & $4.7-13.2$ & - \\
\hline $46-135^{\circ}$ & 11 & 8 & $6.5-15.5$ & - \\
\hline $136-225^{\circ}$ & 7 & 16 & $3.1-10.9$ & -0.52 \\
\hline $226-315^{\circ}$ & 15 & 10 & $10.0-20.0$ & - \\
\hline Drainage bottom & 10 & 19 & $5.1-14.6$ & -0.43 \\
\hline Mesa & 13 & 2 & $7.7-18.3$ & 0.79 \\
\hline Valley floor & 15 & 10 & $9.5-20.4$ & - \\
\hline Lower half of ridge & 6 & 7 & $2.1-9.8$ & - \\
\hline Upper half of ridge & 6 & 9 & $2.1-9.8$ & - \\
\hline Top of ridge & 2 & 5 & $0.3-4.3$ & -0.44 \\
\hline
\end{tabular}

'Jacobs' $D$ represents the magnitude of the selection or avoidance.

calculated Bonferroni confidence intervals $(\alpha<0.1)$ for habitat parameters at flush sites (Neu et al. 1974; Byers et al. 1984). If availability, as determined from nonuse plots, differed from use, we calculated a Jacobs' D selectivity index (Jacobs 1974) to determine magnitude of selection.

We developed logistic-regression models (Hosmer and Lemeshow 1989) to determine which habitat variables best predicted habitat use of scaled quail (Harrell 1980). We assigned 0.5 as the cut-point for classification of flush sites and nonuse plots and used a jackknife resampling procedure (Verbyla and Litvaitis 1989) to evaluate the classification bias of the final model.

\section{RESULTS}

We located 52 groups of scaled quail. We found $70 \%$ of coveys in the morning and early afternoon $(\leq 1400$ hours MST) because increasing temperatures in the afternoons made it difficult for dogs to find scaled quail. We flushed 676 scaled quail, with an average covey size of 13.0 birds/covey $(S D=9.8)$. We were able to classify the activity of $52 \%$ of the coveys found: $15 \%$ were feeding; $9 \%$, roosting or loafing; and $28 \%$, traveling.

\section{Habitat Measurements}

Mean slope at flush sites $\left(3.8^{\circ}\right)$ was low and did not differ from mean slope at nonuse plots (Table 1). Scaled quail avoided south-facing slopes $(P \leq 0.10)$ and used other slope-aspect classes according to availability (Table 2); 10 flush sites and 11 nonuse plots were too flat to estimate slope aspect. We found $29 \%$ of flush sites on valley floors and $25 \%$ on mesas. Scaled quail used mesas more than randomly available and avoided drainage bottoms and ridgetops (Table 2), whereas use of other terrain categories did not differ from expected.

\section{Vegetation Sampling}

Within $100-\mathrm{m}^{2}$ circular plots, species richness was greater at flush sites for grasses and lower for trees than at nonuse plots (Table 3). Species richness for forbs, shrubs, and cacti did not differ between flush sites and nonuse plots (Table 1). Flush sites 
Table 3. Habitat variables at scaled quail flush sites $(n=52)$ that differed $(P \leq 0.0083)$ from nonuse plots $(n=54)$ in southeastern Arizona, October-March, 2002-2004.

\begin{tabular}{lccc}
\hline & \multicolumn{2}{c}{ Mean \pm SD } & \\
\cline { 2 - 3 } Variable & Flush & Nonuse & $P^{1}$ \\
\hline Grass species richness & $3.2 \pm 1.6$ & $1.9 \pm 0.9$ & $<0.001$ \\
Tree species richness & $0.4 \pm 0.6$ & $1.0 \pm 0.5$ & $<0.001$ \\
Distance to nearest tree (m) & $21.4 \pm 30.9$ & $5.4 \pm 7.1$ & 0.001 \\
Grass ground cover (\%) & $31.3 \pm 20.6$ & $15.8 \pm 13.4$ & $<0.001$ \\
Rock ground cover (\%) & $11.4 \pm 12.5$ & $5.0 \pm 7.5$ & 0.002 \\
Bare ground cover (\%) & $25.2 \pm 15.8$ & $40.4 \pm 17.7$ & $<0.001$ \\
Grass canopy cover (\%) & $32.3 \pm 23.0$ & $16.5 \pm 13.5$ & $<0.001$ \\
Tree canopy cover (\%) & $3.4 \pm 5.6$ & $24.4 \pm 14.4$ & $<0.001$ \\
Average grass height (cm) & $22.4 \pm 8.2$ & $16.5 \pm 6.3$ & $<0.001$ \\
Robel pole 10-cm (\%) & $13.8 \pm 16.9$ & $49.5 \pm 28.4$ & $<0.001$ \\
Robel pole 20-cm (\%) & $22.5 \pm 21.2$ & $54.2 \pm 28.7$ & $<0.001$ \\
\hline
\end{tabular}

${ }^{1}$ Differences determined by 2-sample $t$ tests.

${ }^{2}$ Percentage of $10-\mathrm{cm}$ band visible from $1-\mathrm{m}$ height at $10-\mathrm{m}$ distance.

${ }^{3}$ Percentage of $20-\mathrm{cm}$ band visible from $1-\mathrm{m}$ height at $10-\mathrm{m}$ distance.

were farther from trees than were centers of nonuse plots (Table 3 ), yet DBH of the closest tree was not different between flush sites and nonuse plots (Table 1). Mesquite trees were the most common trees near flush sites (89\% of flush sites) and nonuse plots $(91 \%$ of nonuse plots), and scaled quail used areas with tree and shrub species according to availability $(P \geq 0.10)$. Distances to the nearest shrub were not different between flush sites and nonuse plots (Table 1).

Percentage of ground and canopy cover characteristics were different between flush sites and nonuse plots. Ground cover at flush sites had higher percentages of grasses and rocks, and lower percentages of bare ground, than did nonuse plots (Table 3). Flush sites had higher percentages of grass canopy, and lower levels of tree canopy, than did nonuse plots (Table 3). Percentage of forb, shrub, cacti, tree, and litter ground cover and the percentage of forb, shrub, and cacti canopy cover were not different between flush sites and nonuse plots (Table 1).

Table 4. Use, by percentage, of grass and tree canopy cover class at scaled quail flush sites $(n=52)$ compared with nonuse plots $(n=54)$ in southeastern Arizona, October-March, 2002-2004.

\begin{tabular}{lcccc}
\hline $\begin{array}{l}\text { Aspect/terrain } \\
\text { class }\end{array}$ & $\begin{array}{c}\text { No. of } \\
\text { locations }\end{array}$ & $\begin{array}{r}\text { No. of } \\
\text { locations } \\
\text { expected }\end{array}$ & $\begin{array}{c}\text { Bonferroni } \\
90 \% \mathrm{Cl}\end{array}$ & $\begin{array}{c}\text { Jacobs' } \\
D^{1}\end{array}$ \\
\hline $\begin{array}{c}\text { Grass canopy } \\
0-25 \%\end{array}$ & 17 & 30 & $11.6-22.3$ & -0.47 \\
$26-50 \%$ & 12 & 13 & $7.2-16.8$ & - \\
$51-75 \%$ & 7 & 6 & $3.7-10.9$ & - \\
$76-100 \%$ & 16 & 3 & $10.8-21.2$ & 0.76 \\
Tree canopy & & & & \\
$0-5 \%$ & 38 & 4 & $33.0-43.0$ & 0.94 \\
$6-10 \%$ & 8 & 5 & $3.9-12.1$ & - \\
$11-15 \%$ & 3 & 8 & $0.4-5.7$ & -0.53 \\
$\geq 16 \%$ & 3 & 35 & $0.4-5.7$ & -0.94 \\
\hline
\end{tabular}

'Jacobs' $D$ represents the magnitude of the selection or avoidance.

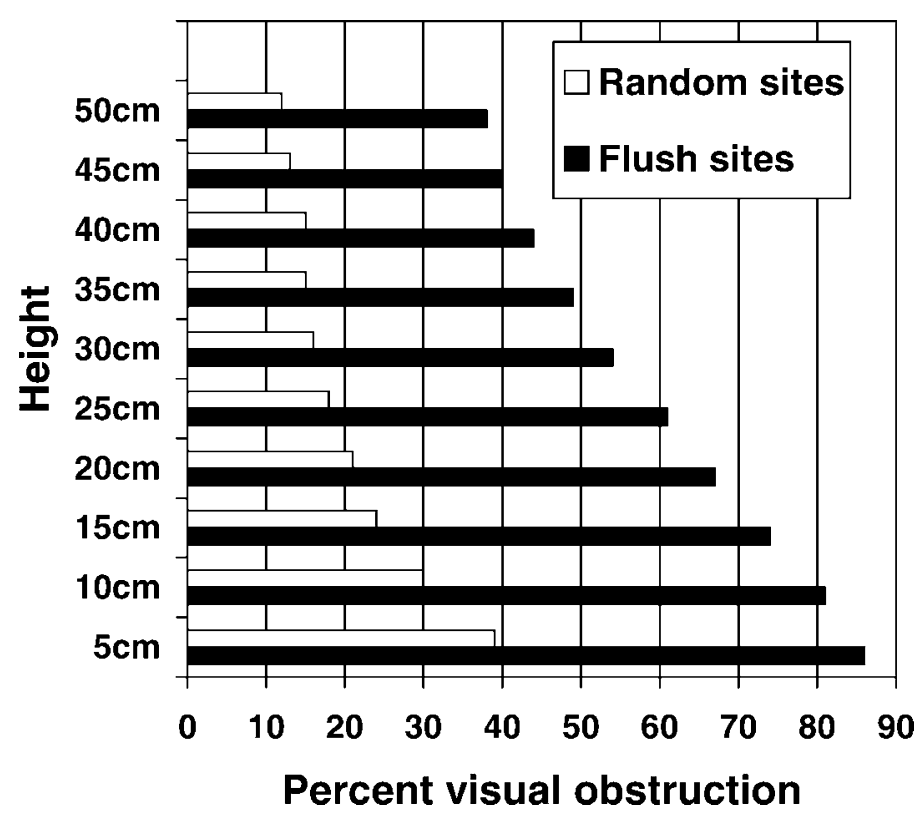

Figure 1. Average visual obstruction by height class as determined by visibility board readings taken at scaled quail flush sites $(n=52)$ compared with nonuse plots $(n=54)$ in southeastern Arizona, OctoberMarch, 2002-2004. All differences are significant $(P \leq 0.10)$ according to 2-sample $t$ tests.

Average grass height was greater at flush sites than nonuse plots (Table 3). Scaled quail avoided areas that had $\leq 25 \%$ grass canopy cover $(>10 \mathrm{~cm}$ high) and selected areas that had $>75 \%$ grass canopy cover (Table 4 ). Scaled quail also avoided areas that had $>10 \%$ tree canopy cover and selected areas that had $\leq 5 \%$ tree canopy cover (Table 4 ).

Both methods that we used to measure visual obstruction showed that scaled quail used areas with more visual obstruction than found at nonuse plots. The percentages of both $10-\mathrm{cm}$ and $20-\mathrm{cm}$ bands of the Robel pole visible from $10-\mathrm{m}$ distance were smaller at flush sites than at nonuse plots (Table 3). Visual obstruction was greater at flush sites for all 10 height levels of the visibility board than that seen at nonuse plots $(P \leq 0.001$; Fig. 1).

Tree canopy, grass canopy, and estimates of low-level $(\leq 10$ $\mathrm{cm})$ cover were important variables predicting scaled quail habitat use (Table 5). The most successful model (Model 1) correctly classified $94.2 \%$ of flush sites and $88.9 \%$ of nonuse plots. A jackknifed classification of Model 1 correctly classified 48 of 52 flush sites and 49 of 54 nonuse plots for an overall misclassification rate of $\leq 8.5 \%$.

\section{DISCUSSION}

Scaled quail used areas that had greater amounts of low-level cover and greater amounts of grass cover and that were nearly devoid of trees. These findings are similar to previous general descriptions of scaled quail habitat (Schemnitz 1961; Anderson 1974). Our best predictive model also demonstrated the importance of greater low-level cover and reduced tree canopy cover. Human activities in Arizona that can affect these habitat components include livestock grazing, fire suppression, and 
introduction of exotic grasses. Habitat use patterns that we observed can be largely explained by the specific diet and security requirements of the scaled quail, and they illustrate the need for proper range management to ensure these habitat requirements are maintained.

Scaled quail primarily feed on seeds of forbs and grasses, switching to green herbage and insects when available (Medina 1988). Whereas we found scaled quail used areas with more diverse grasses and greater percentages of grass ground and canopy cover, we also found that forb diversity and ground cover did not seem to affect habitat use. Wallmo (1957) suggested that grazing might decrease food and cover resources available to scaled quail while promoting a more diverse weed flora, creating a boom-or-bust environment, which would result in boom-or-bust quail populations with increasing busts as time progresses.

Use of areas with greater grass canopy and visual obstruction is likely related to scaled quail security requirements. Scaled quail tend to run, disperse coveys, and hide in response to danger (Schemnitz 1994); this behavior is well suited to the habitats they use. Whereas average grass height and canopy cover were greater at flush sites, we found scaled quail used areas with a lower percentage of grass canopy than that used by Montezuma quail (Bristow and Ockenfels 2004), a species that tends not to run. Areas with relatively open ground cover allow scaled quail to move easily; however, a patchy distribution of grass, shrub, and cactus cover is necessary to provide hiding and loafing cover (Schemnitz 1961). Generally, scaled quail use areas with dense shrub and grass patches separated by extensive areas of open bare ground (Anderson 1974; Stormer 1984). Anderson (1974) found that scaled quail avoided brushy riparian vegetation types in southeastern Arizona. We found that although shrub density did not affect scaled quail use at the microsite level, areas with $>20 \%$ tree cover were nearly devoid of scaled quail.

Exotic grass invasion is considered a pervasive problem in arid grasslands of the southwestern United States (Kuvlesky et al. 2002). Exotic grasses can aggressively invade areas, thereby displacing native species and reducing plant species diversity; this can eventually reduce insect and bird biodiversity (Bock et al. 1986). Several areas within our study area were dominated by Lehmann lovegrass (Eragrostis lehmanniana Nees.), almost to the exclusion of all other grasses. Like Medina (1988), we found very few scaled quail in these monotypic habitats. We found that scaled quail used areas with higher grass species richness. Other studies have found that scaled quail favor areas with more diverse plant species composition and structure (Campbell-Kissock et al. 1985; King 1998). Cattle usually avoid grazing Lehmann lovegrass; therefore, high grazing intensities can increase the relative abundance of this species (McClaran and Anable 1992).

\section{MANAGEMENT IMPLICATIONS}

Proper range management that allows residual grasses and forbs to persist through the winter could result in reduced scaled quail mortality and an increase in local populations (Brown 1989). Whether this management strategy could be used to sustain scaled quail populations remains to be tested
Table 5. Logistic-regression models ${ }^{1}$ differentiating scaled quail flush sites $(n=52)$ from nonuse plots $(n=54)$ in southeastern Arizona, October-March, 2002-2004.

\begin{tabular}{lcc}
\hline & $\begin{array}{c}\text { \% Flush sites } \\
\text { correctly } \\
\text { classified }\end{array}$ & $\begin{array}{c}\% \text { Nonuse plots } \\
\text { correctly } \\
\text { classified }\end{array}$ \\
\hline Mode $^{2}$ & & \\
\hline $\begin{array}{l}\text { 1. } Z=2.60-0.20 \text { TREECAN }-0.04 \\
\text { ROBEL10-cm }+0.03 \text { GRSSCAN }\end{array}$ & 94.2 & 88.9 \\
2. $Z=1.36-0.20$ TREECAN -0.04 & & \\
$\quad$ ROBEL10-cm ${ }^{3}+0.10$ GRASSHT & 94.2 & 87.0 \\
3. $Z=-0.93-0.16$ & & \\
$\quad$ TREECAN +0.46 OBSTR10-cm & 92.3 & 88.9 \\
$\begin{array}{l}\text { 4. } Z=2.22-0.21 \text { TREECAN } \\
\text { 5. } Z=0.47-0.06\end{array}$ & 88.5 & 83.3 \\
ROBEL10-cm +0.14 DISTNCE & 88.5 & 85.2 \\
\hline
\end{tabular}

${ }^{1} P$ values for all models were $<0.001$, and degrees of freedom were equal to the number of variables in the model.

${ }^{2} Z$ = probability of use by scaled quail; TREECAN, percentage of tree canopy cover; ROBEL10, percentage of 10-cm band visible from 1-m height at 10-m distance; GRSSCAN, percentage of grass canopy cover; GRASSHT, average grass height; OBSTR10, amount of visual obstruction at $10-\mathrm{cm}$ height; DISTNCE, distance $(\mathrm{m})$ to nearest 2-m tree.

(Brennan 1994). Given the habitat use patterns of scaled quail that we observed, it is clear that land management practices that significantly reduce grass species richness, cover, and height and that increase tree cover would reduce winter habitat availability to scaled quail. We recommend that semidesert grassland habitats contain a maximum tree canopy of $<6 \%$ and $>25 \%$ grass canopy cover at the $20-\mathrm{cm}$ height to provide optimum cover availability.

\section{ACKNOWLEDGMENTS}

Authors wish to thank Mike Rabe for assistance in statistical analysis, Sue Boe for assistance with geographic information systems functions, and reviewers for providing valuable editorial comments.

\section{LITERATURE CITED}

Anderson, W. L. 1974. Scaled quail: social organization and movements [MS thesis]. Tucson, AZ: University of Arizona. $132 \mathrm{p}$.

Arthur, S. M., B. F. J. Manly, L. L. McDonald, and G. W. Gardner. 1996. Assessing habitat selection when availability changes. Ecology 77:215-227.

Bock, C. E., J. H. Bock, K. L. Jepson, And J. C. ORtega. 1986. Ecological effects of planting African lovegrass in Arizona. National Geographic Research 2: 456-463.

Brennan, L. A. 1994. Broad-scale population declines in four species of North American quail: An examination of possible causes. In: Sustainable ecological systems: Implementing an ecological approach to land management. Fort Collins, C0: USDA-Forest Service, Rocky Mountain Forest and Range Experiment Station. General Technical Report Rm-247. p 44-50.

Bristow, K. D., AND R. A. Ockenfels. 2004. Pairing season habitat selection by Montezuma quail in southeastern Arizona. Journal of Range Management 57:532-538.

Brown, D. E. 1978. Grazing, grassland cover and gamebirds. Transactions of the 43rd North American Wildlife and Natural Resources Conference; 18-22 March 1978; Phoenix, AZ. Washington, DC: Wildlife Management Institute. p 477-485.

Brown, D. E. 1989. Scaled quail. In: Arizona game birds. Tucson, AZ: University of Arizona Press, and Arizona Game and Fish Department. p 145-161. 
Brown, D. E. 1994a. Semidesert grassland. In: D. E. Brown [ed.]. Biotic communities: Southwestern United States and northwestern Mexico. Salt Lake City, UT: University of Utah Press. p 123-131.

Brown, D. E. 1994b. Chihuahuan desertscrub. In: D. E. Brown [Ed.]. Biotic communities: Southwestern United States and northwestern Mexico. Salt Lake City, UT: University of Utah Press. p 169-179.

Byers, C. R., R. K. Steinhorst, and P. R. Krausman. 1984. Clarification of a technique for analysis of utilization-availability data. Journal of Wildlife Management 48:1050-1053.

Campbell-Kissock, L., L. H. Blankenship, and J. W. Stewert. 1985. Plant and animal foods of bobwhite and scaled quail in southwest Texas. Southwestern Naturalist 30:543-553.

HarReLl, F. 1980. The logistic procedures. In: P. S. Reinhardt [ed.]. SAS supplemental library user's guide. Cary, NC: SAS Institute Inc. p 83-102.

HoCHBERG, Y. 1988. A sharper Bonferroni procedure for multiple tests of significance. Biometrika 75:800-802.

Hosmer, D. W., JR., AND S. Lemeshow. 1989. Applied logistic regression. New York, NY: John Wiley and Sons. $307 \mathrm{p}$.

JACOBS, J. 1974. Quantitative measurements of food selection. Oecologia 14:413-417.

KING, N. M. 1998. Habitat use by endangered masked bobwhites and other quail on the Buenos Aires National Wildlife Refuge, Arizona [MS thesis]. Tucson, AZ: University of Arizona. $111 \mathrm{p}$.

Kuvlesky, W. P., T. E. Fulbright, and R. Engel-Wilson. 2002. The impact of invasive exotic grasses on quail in the southwestern United States. Quail V: Proceedings of the 5th National Quail Symposium; 23-27 January 2002; Corpus Christi, TX. Austin, TX: Texas Parks and Wildlife Department. p 118-128.

McClaran, M. P., and M. E. Anable. 1992. Spread of introduced Lehmann lovegrass along a grazing intensity gradient. Journal of Applied Ecology 29:92-98.
Medina, A. L. 1988. Diets of scaled quail in southern Arizona. Journal of Wildlife Management 52:753-757.

National Oceanic and Atmospheric Administration. 2003. Arizona climatological data. Volume 107. Ashville, NC: National Climatic Data Center.

Neu, C. W., C. R. Byers, and J. M. Peek. 1974. A technique for analysis of utilization-availability data. Journal of Wildlife Management 38:541-545.

Robel, R. J., J. N. Briggs, A. D. Dayton, and L. C. Hulbert. 1970. Relationship between visual obstruction measurements and weight of grassland vegetation. Journal of Range Management 23:295-297.

Saiwana, L., J. L. Holechek, A. Tembo, R. Valdez, and M. Cardenas. 1998. Scaled quail use of different seral stages in the Chihuahuan Desert. Journal of Wildlife Management 62:550-556.

Schemnitz, S. D. 1961. Ecology of the scaled quail in the Oklahoma panhandle. Wildlife Monographs $8.47 \mathrm{p}$.

Schemnitz, S. D. 1994. Scaled quail (Callipepla squamata). In: A. Poole and F. Gill [EDS.]. The birds of North America 106. Philadelphia, PA: The Birds of North America, Inc. p 1-2.

StORMER, F. A. 1984. Night roosting habitat of scaled quail. Journal of Wildlife Management 48:191-197.

Turner, R. M., and D. E. Brown. 1994. Sonoran desertscrub. In: D. E. Brown [ED.]. Biotic communities: Southwestern United States and northwestern Mexico. Salt Lake City, UT: University of Utah Press. p. 181-221.

Verbyla, D. L., AND J. A. Litvaitis. 1989. Resampling methods for evaluating classification accuracy of wildlife habitat models. Environmental Management 13:783-787.

Wallmo, O. C. 1957. Ecology of scaled quail in west Texas. Austin, TX: Texas Game and Fish Commission. Special Report P-R Project W-57-R. 134 p.

ZaR, J. H. 1984. Biostatistical analysis. 3rd ed. Englewood Cliffs, NJ: Prentice-Hall. $718 \mathrm{p}$. 